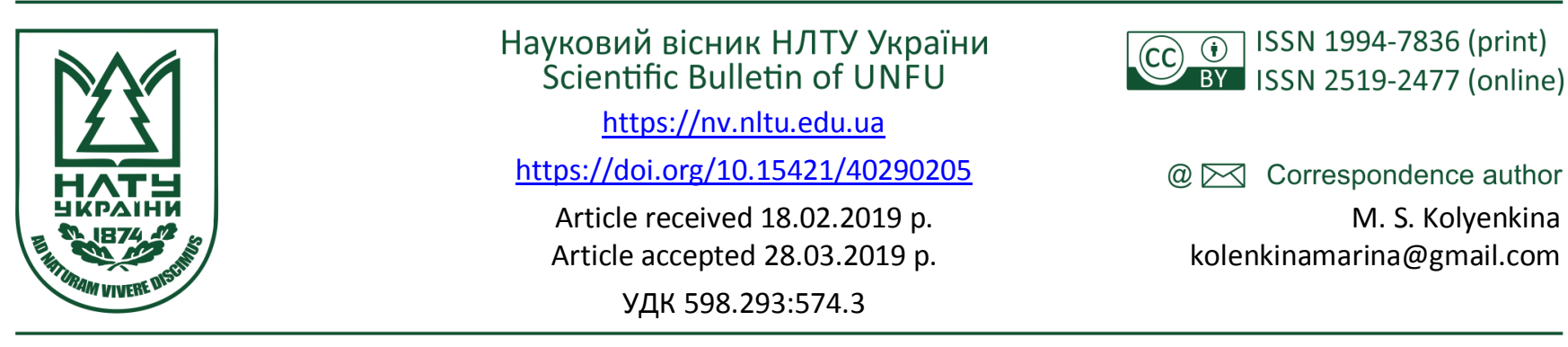

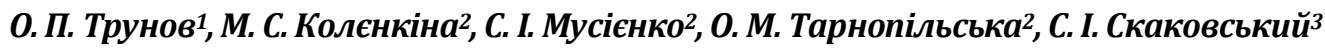

${ }^{l}$ Харківський національний аграрний університет ім. В. В. Докучаєва, м. Харків, Украӥна

${ }^{2}$ Харківський національний університет міського господарства ім. О. М. Бекетова, м. Харків, Україна

${ }^{3}$ Луганський національний університет ім. Тараса Шевченка, м. Старобільськ, Украӥна

\title{
ДИНАМІКА ПОПУЛЯЦІЙ ВОРОНОВИХ І ЇХНІЙ ВПЛИВ НА МИСЛИВСЬКУ ФАУНУ ЛУГАНСЬКОЇ ОБЛАСТІ
}

Досліджено багаторічну (1983-2013рр.) динаміку щільності популяцій птахів родини Воронових (Corvidae) у мисливських угіддях Щетівського лісництва Іванівського ДЛМГ Луганської області. Щільність популяцій визначено методом мар-

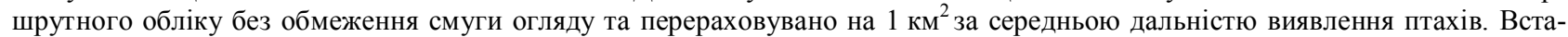
новлено, що за 30 років щільність популяції ворона в регіоні досліджень збільшилася в 11,5 раза - від 0,1 до 1,15 екз./км², щільність популяції ворони сірої зменшилася в 11,1 раза - від 3,4 до 0,3 екз./км², сороки - у 2,4 раза, граків і галок - у 9,2 та 2 рази відповідно, сойки - в 1,6 раза. Визначено тісний від'ємний зв'язок між щільністю популяцій ворона та інших досліджених видів воронових, найтісніший - між щільністю популяцій ворона та ворони сірої, з огляду на близьку екологію цих двох видів із перевагами ворона як більш великого та агресивного виду. Проаналізовано залежність щільності популяцій ворона, ворони сірої, сороки, грака, галки та сойки від особливостей живлення, місць поселення, шкоди для об'єктів полювання та антропогенних чинників (зміни системи обробітку грунту, структури посівних площ, ліквідації тваринницьких комплексів тощо). Рекомендовано спростити одержання дозволів на відстріл ворона, який завдає великої шкоди об'єктам полювання (крижню та іншим качкам, фазану, куріпці сірій та зайцю-русаку).

Ключові слова: ворон; ворона сіра; сорока; грак; галка; сойка.

Вступ. Представники родини Воронові (Corvidae) належать до понад 100 видів із 26 родів і поширені на всіх континентах, окрім Антарктиди (Marzluff et al., 1998; Zawadzka \& Zawadzki, 2014; Bagyura et al., 2017; Kövér et al., 2018). У фауні України відомо 10 видів, серед яких найпоширенішими є ворон (Corvus corax), ворона сіра (Corvus (corone) cornix), грак (Corvus frugilegus), галка (Corvus monedula), сойка (Garrulus glandarius), сорока (Pica pica) (Vetrov \& Milobog, 1993; Moroz et al., 2008; Kopylova et al., 2011; Lopar'ov, 2007; Matyura \& Zimaroeva, 2016). Раціон живлення воронових дуже різноманітний - від плодів і насіння (Kitowski et al., 2017), яєць і пташенят різних видів птахів (Chmielewski, 2015) до залишків їжі людини на сміттєзвалищах (Madden et al., 2015). У природних умовах воронові селяться у перелісках, балках, біля водойм (Volchanetsky et al., 1954; Marzluff \& Restani, 1999; Teplov \& Turov, 2013; Roos et al., 2018), де відіграють позитивну роль у перенесенні насіння багатьох видів рослин (Kitowski et al., 2017) і негативну - у руйнуванні гнізд інших птахів
(Roos et al., 2018). Під час масового розмноження у містаx (Marzluff \& Neatherlin, 2006; Zawadzka \& Zawadzki, 2014; Fero et al., 2018) воронові заважають людині, спричиняючи гам, утворюючи додаткове сміття, нападаючи на птахів, дрібних собак і кішок (Kövér et al., 2018). 3 огляду на це в різних країнах призначають заходи щодо зменшення шкоди від цих птахів, зокрема застосування пасток і прямий відстріл (Špur et al., 2016; Sage \& Aebischer, 2017), що позначається на динаміці популяцій окремих видів.

Орнітофауну Луганської обл. вивчали ще в середині XX ст. (Volchanetsky et al., 1954), а в наступні роки відомо лише поодинокі публікації стосовно хижих птахів, зокрема воронових (Vetrov \& Milobog, 1993; Moroz et al., 2008). Водночас, за даними статистичної звітності, у Луганській обл. за 35 років (1983-2013 рр.) зменшилася чисельність мисливських видів птахів і зайцярусака - основних об'єктів спортивного полювання. Значну роль у цьому відіграли як екологічні чинники, так і діяльність людини, зокрема стосовно стратегії й

Інформація про авторів:

Трунов Олександр Петрович, канд. с.-г. наук, доцент, кафедра садово-паркового господарства. Email: alex35agro@ukr.net

Колєнкіна Марина Сергіївна, канд. с.-г. наук, доцент, кафедра лісового та садово-паркового господарства. Email: kolenkinamarina@gmail.com

Мусієнко Сергій Іванович, канд. с.-г. наук, доцент, кафедра лісового та садово-паркового господарства. Email: kolenkinamarina@gmail.com

Тарнопільська Оксана Михайлівна, канд. с.-г. наук, доцент, ст. наук. співробітник, кафедра лісового та садово-паркового господарства. Email: tarnopilskaya@gmail.com

Скаковський Сергій Іванович, асистент, кафедра садово-паркового господарства та eкологіï. Email: ssk24@ukr.net

Цитування за ДСтУ: Трунов О. П., Колєнкіна М. С., Мусієнко С. І., Тарнопільська О. М., Скаковський С. І. Динаміка популяцій воронових і їхній вплив на мисливську фауну Луганської області. Науковий вісник НЛтУ України. 2019, т. 29, № 2. С. 26-30.

Citation APA: Trunov, O. P., Kolyenkina, M. S., Musiyenko, S. I., Tarnopyl'ska, O. M., \& Skakovs'kyy, S. I. (2019). Population dynamics of corvids and their influence on the hunting fauna in the Luhansk region. Scientific Bulletin of UNFU, 29(2), 26-30.

https://doi.org/10.15421/40290205 
тактики полювання. Не останню роль відіграли зміни внаслідок зазначених причин видового складу й чисельності хижих птахів. Тому наші дослідження видів родини воронових, які $є$ найбільш численними серед пернатих хижаків, є актуальними.

Метою ичєё роботи є виявлення особливостей і причин багаторічної динаміки популяцій ворона, ворони сірої, сороки, грака, галки, сойки в мисливських угіддях і розроблення рекомендацій щодо регулювання їхньої чисельності.

Матеріали і методи дослідження. Дослідження провели на території Щетівського лісництва Іванівського ДЛМГ Луганської обл. Територія об'єкта розташована в південній частині Луганської обл., рельєф складний, межує переважно із сільськогосподарськими угіддями (78,7 \% площі). На 3030 га лісових угідь припадає п'ять населених пунктів. Об'єкти ПЗФ на території лісництва відсутні.

Дані з офіційних джерел (за даними таксаційних обстежень, які здійснює мисливське господарство) використовували дуже обережно, тому що іноді користувачі мисливських угідь "коригують" дані, щоб надати можливість рядовим мисливцям узяти участь у полюванні.

Тому переважно використовували дані власних обліків, які здійснювали у 1983-2013 pp., за винятком 1985, 1992, 2002 та 2009 рр., методом маршрутного обліку без обмеження смуги огляду з розрахунком щіль-

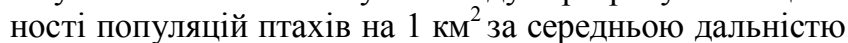
їхнього виявлення (Ravkin \& Chelintsev, 1990).

Трансекти формують маршрути у вигляді ламаних ліній, що забезпечує рівномірніше представництво центральних і периферійних частин виділів. Протяжність облікової лінії становила в кожному сезоні не менше 20 км у кожному з виділених типів місцеперебування.

Під час обліку реєстрували всіх виявлених птахів, окрім тих, яких бачили за межами досліджуваного місцеперебування. Хід чергували із зупинками, швидкість руху під час обліку сягала 3 км/год. Щільність популяцій визначали з урахуванням пройденої відстані без обмеження облікової смуги з наступним роздільним розрахунком показників щільності за інтервалами дальності виявлення. Обліки здійснювали переважно у першій половині дня. Відстані визначали окомірно. Всі дані щодо кожного обліку заносили на карточки, де також реєстрували географічне положення і тип місцеперебування, протяжність маршруту, дату і час обліку та його витрати, погодні умови. Записували одержані відомості стосовно виду птахів, кількості особин, характеру активності, виміряної відстані. Результати всіх обліків у кожному місцеперебуванні за сезон об'єднували у зведену таблицю для розрахунку щільності популяцій для кожного виду окремо (Ravkin \& Chelintsev, 1990).

Результати дослідження. На території Щетівського лісництва у період досліджень переважали види родини Воронові: ворон (Corvus corax), ворона сіра (Corvus (corone) cornix), грак (Corvus frugilegus), галка (Corvus monedula), сойка (Garrulus glandarius), сорока (Pica pica). Серед інших птахів визначали підвищену чисельність канюка звичайного (Buteo buteo) та зимняка (Buteo lago$p u s)$. Значно меншою була чисельність луня болотного (Circus aeruginosus), яструба великого (Accipiter gentilis), яструба малого (Accipiter nisus), боривітру звичайного (Falco tinnunculus) та сов. За роки досліджень чисельність популяцій зазначених видів змінювалася у значних межах $(\mathrm{P}<0,05)$.
Ворон у 1980-ті роки траплявся не дуже часто, групами по 2-4 особини, а нині чисельність ворона у зграї сягає 20-30 (максимально 74) особин. Загальна чисельність популяції зросла за 30 років у 11,5 раза - від 0,1 до 1,15 екз./км² (рис. 1 ).

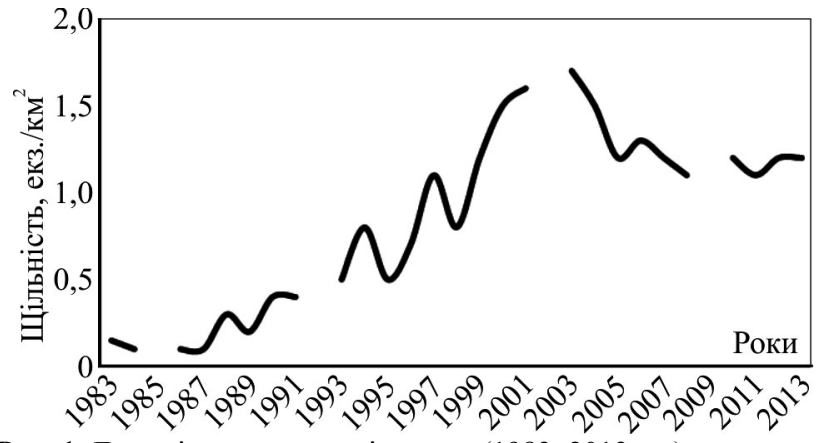

Рис. 1. Динаміка чисельності ворона (1983-2013 рр.)

Найбільш значущою причиною такого стрімкого підвищення чисельності ворона вважаємо спорудження у 80-х роках XX ст. ліній високовольтних передач, на опорах яких ворон одержує ідеальні умови для гніздування та вистежування здобичі (Bagyura et al., 2017). Зі збільшенням віку лісових смуг ворон мав змогу гніздуватися також на великих деревах. За даними статистичної звітності, значне збільшення чисельності во́рона призвело до зменшення у 3-7 разів чисельності основних об'єктів полювання: крижня та інших качок, фазана, куріпки сірої та зайця-русака.

Водночас починаючи від 2006 р., чисельність ворона дещо зменшилася - на 25-30 \%, порівняно, з 2005 р.

Ворона сіра, на відміну від ворона, була у 80 -ті роки $\mathrm{XX}$ ст. доволі численною, iї винищували мисливці як хижака мисливських видів (як це було наказано всім власникам мисливських квитків). Останнім часом більший і агресивніший вид - ворон - практично повністю захопив їі екологічну нішу, а чисельність ворони сірої знизилася в 11,1 раза - від 3,4 до 0,3 екз./км² (рис. 2).

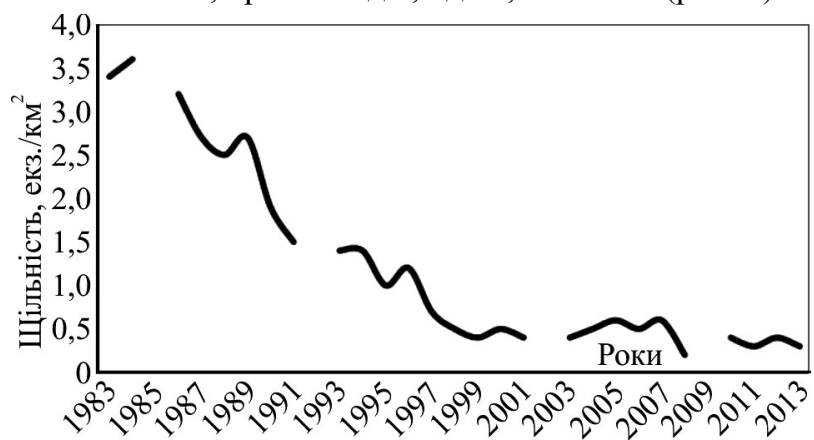

Рис. 2. Динаміка чисельності ворони сірої (1983-2013рр.)

Сорока останнім часом трапляється набагато рідше, ніж на початку досліджень - iї чисельність знизилася в середньому в 2,4 раза (рис. 3 ). У радянські часи сороку переслідували мисливці як "молодшу сестру" ворони сіpoï, а також за "балакучість" на колективних полюваннях.

Чисельність колись звичайних в угіддях граків і галок зменшилася у 9,2 та 2 рази відповідно (рис. 4). Таке зниження пов'язано насамперед із майже повною ліквідацією тваринницьких ферм великої рогатої худоби, де раніше галки та граки годувалися сотнями.

Чисельність популяції сойки за 30 років зменшилася в 1,6 раза (рис. 5). Помітного негативного впливу сойки на стан мисливської фауни не виявлено. 


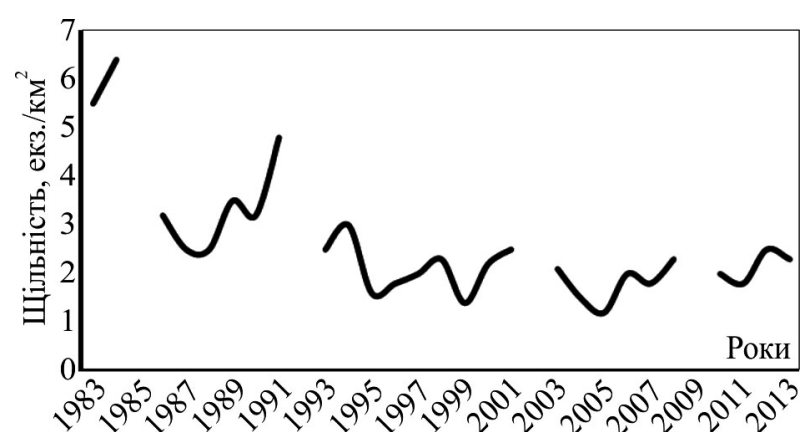

Рис. 3. Динаміка чисельності сороки (1983-2013 pp.)

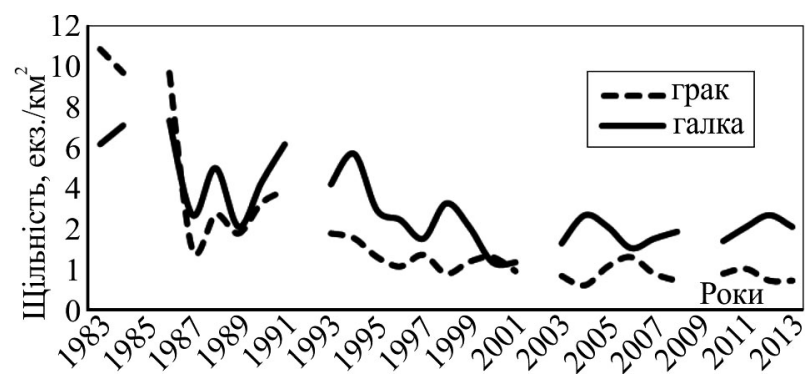

Рис. 4. Динаміка чисельності грака та галки (1983-2013 pp.)

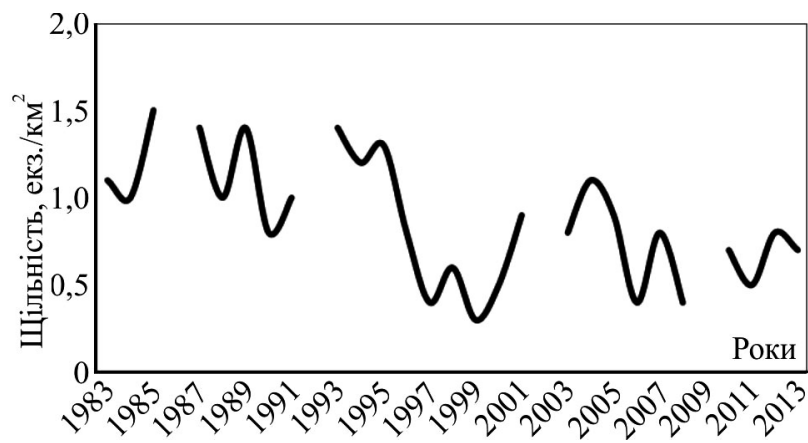

Рис. 5. Динаміка чисельності сойки (1983-2013рp.)

Серед видів інших родин за останні 10-12 років канюк звичайний та зимняк стали звичайними в мисливських угіддях, хоча їхній вплив на мисливську фауну значно менший, ніж вплив ворона. Чисельність великого й малого яструбів знизилася у 2,0-2,4 раза, боривітер майже зник, а лунь болотний трапляється зрідка. Кореляційний аналіз виявив тісний від'ємний зв'язок між щільністю популяцій ворона та інших досліджених видів воронових (r -0,888 - -0,630) (таблиця).

Найтісніший від'ємний зв'язок виявлено між щільністю популяції ворона та ворони сірої. Показники щільності популяцій інших воронових (ворони сірої, сойки, сороки, галки, грака) пов'язані між собою прямою кореляцією $(r-0,429-0,857)$. Це свідчить про наявність найбільш вираженої конкуренції між двома видами 3 близькою екологією - вороною і вороною сірою, де ворона сіра поступається своєму вищому, агресивнішому та сильнішому "родичу".

Таблиця. Результати кореляційного аналізу щільності популяцій різних видів воронових (1983-2013 рр.)

\begin{tabular}{|c|c|c|c|c|c|c|}
\hline Вид & Ворон & $\begin{array}{c}\text { Воро- } \\
\text { на сіра }\end{array}$ & Сорока & Грак & Галка & Сойка \\
\hline Ворон & $\times$ & $-0,888$ & $-0,630$ & $-0,704$ & $-0,772$ & -0634 \\
\hline Ворона сіра & & $\times$ & 0,751 & 0,857 & 0,764 & 0,799 \\
\hline Сорока & & & $\times$ & 0,830 & 0,726 & 0,708 \\
\hline Грак & & & & $\times$ & 0,820 & 0,429 \\
\hline Галка & & & & & $\times$ & 0,548 \\
\hline Сойка & & & & & & $\times$ \\
\hline
\end{tabular}

Обговорення отриманих результатів дослідження. У 80-ті роки $\mathrm{XX}$ ст. доволі суворо дотримувалися положень законодавства про охорону рідкісних видів, зокрема ворона. Він зрідка гинув у мисливських угіддях - корму вистачало, природних ворогів він практично не мав, потрапляв під постріл нечасто, оскільки з усіх видів родини ворон є найбільш обережним - озброєну людину на відкритому просторі підпускає не ближче $100 \mathrm{M}$.

Важливу роль у підтриманні високої чисельності ворона відіграв той факт, що у 80-90-ті роки XX ст. мисливцям на законодавчому рівні було дозволено знищувати його основного конкурента - ворони сірої. Так, місцеві мисливці добували до 80-100 екземплярів ворони сірої на рік (з урахуванням здобичі пташенят під час руйнування її гнізд пострілами картечі).

У раціоні живлення ворона у 80-90-х роках XX ст. значну частку становили підранки зайців і пернатих (качок, фазанів). На початку 2000-х років ворон навчився "колективному" полюванню групами по 8-0 особин на молодь зайця-русака.

Мисливська територія ворона не приурочена до дислокації населених пунктів - найчастіше він трапляється поблизу лісових смуг стиглого віку, які межують із великими масивами сільськогосподарських угідь.

Щоправда останнім часом почастішали випадки відстрілу ворона для одержання трофеїв - виготовлення чучел.

Ворона сіра за наявної чисельності поступилася місцем своєму основному конкуренту - ворону - внаслідок антропогенної діяльності, спрямованої на іiї знищення. Водночас, оскільки ворона сіра є пластичним видом, критичного зниження іiі чисельності не відбулося. Цей вид є обережним і припускає наближення озброєної людини на відкритому просторі не ближче, ніж на граничну відстань пострілу з гладкоствольної зброї - 50-70 м.

Негативний вплив ворони сірої на об'єкти мисливського господарства полягає в розкльовуванні кладок яєць качок, фазана, куріпки сірої, а також полювання на зайченят у літній період.

Мисливська територія ворони сірої - переліски, водойми, балки, сіножаті, пасовища, а також територія населених пунктів. Вона гніздиться у лісових смугах і на високих деревах на околицях сіл.

Сорока за обережністю поступається ворону та вороні сірій і часто підпускає людину на відстань пострілу. 3 погляду мисливського господарства, сорока завдає шкоди, живлячись кладками яєць і пташенятами польових видів пернатих, а також куликів. Територія полювання сороки - масиви листяних насаджень, полезахисні лісові смуги, балки, територія населених пунктів. Сорока гніздиться в лісових смугах і на високих деревах на околицях сіл.

Сорока зберігає свою екологічну нішу, відчутної шкоди мисливському господарству не завдає, для побоювань стосовно зниження іiї чисельності немає підстав.

Найбільшої шкоди популяціям галки та грака заподіяли екстремальні снігопади зими 1986-1987 рр., високий сніговий покрив і льодова кірка. За таких умов галки та особливо граки не могли добути корм і гинули тисячами. У наступні роки чисельність популяції галки як більш екологічно пластичного виду, ніж грак, швидко відновлювалася. Водночас після ліквідації тваринницького сектора на сільськогосподарських підприємствах наприкінці XX ст. чисельність популяції галки зменшилася вдвічі, а грака - у 9,2 раза. 
Починаючи з 2000 р., в мисливських угіддях галка і грак трапляються спорадично, переважно на полях, де ще практикують відвальну оранку. Там ці птахи полюють на мишоподібних гризунів, зокрема на мишу садову або степову (Mus hortulanus). На чисельність мисливської фауни галка і грак помітно не впливають, i ïx не добувають як трофеї. Граки та галки гніздяться переважно колоніями на околицях населених пунктів і в самих населених пунктах. Стосовно людини галка набагато обережніша, ніж грак. Територія полювання сойки, як і сороки, - масиви листяних насаджень, полезахисні лісові смуги, балки, територія населених пунктів. Гніздиться у лісових смугах і в населених пунктах.

3 огляду на те, що зміни популяції птахів родини воронові відбулися на користь ворона переважно під впливом антропогенних чинників, доцільно розробити та запровадити на законодавчому рівні ефективні заходи щодо регулювання чисельності ворона. Досвід Західної Європи, зокрема Німеччини (Kopylova et al., 2011), свідчить про доцільність спрощення процедури одержання дозволів на відстріл ворона, зокрема 3 використанням потужної пневматичної та малокаліберної зброї (22 калібр), забезпеченої оптикою, та введення символічного заохочення (що важливо для молодих мисливців-початківців) за вживання цього біотехнічного заходу.

Висновки. Щільність популяцій грака, ворони сірої, галки та сойки на території Щетівського лісництва за 1983-2013 pp. істотно зменшилася, найдужче - ворони сірої та грака. Найбільш різкі зміни чисельності воронових відзначено у 1990-1999 рр. під час різкої зміни структури посівних площ і структури тваринництва.

Значне збільшення чисельності найбільш агресивного виду - ворона - призвело до зменшення у 3-7 разів чисельності основних об'єктів полювання: крижня та інших качок, фазана, куріпки сірої та зайця-русака.

Зазначені зміни пов'язані зі змінами системи обробітку грунту, структури посівних площ в агропромисловому комплексі, ліквідацією тваринницьких комплексів та іншими чинниками антропогенного впливу на екосистеми.

Доцільно спростити одержання дозволів на відстріл ворона та ввести заохочення за здійснення цього біотехнічного заходу.

Подяки. Автори висловлюють глибоку вдячність Образцову Геннадію Анатолійовичу, єгеру Іванівського ДЛМГ, видатному мисливцю та аматору природи за неоціненний внесок в організацію та проведення досліджень.

\section{Перелік використаних джерел}

Bagyura, J., Fidlóczky, J., Schwartz, V., \& Tóth, L. (2017). Interesting breeding cases of the Raven (Corvus corax) in Hungary. Ornis Hungarica, 25(1), 39-43. https://doi.org/10.1515/orhu-2017-0003.

Chmielewski, S. (2015). Observations of Jackdaws Corvus monedula Robbing Nests. International Studies on Sparrows, 39(1), 28-31. https://doi.org/10.1515/isspar-2015-0032.

Fero, O., Ban, M., \& Barta, Z. (2018). Spatio-temporal structure and reproductive success in a rook (Corvus frugilegus) colony. BioRxiv. https://doi.org/10.1101/409664

Kitowski, I., Sandor, A. D., Czarnecka, J., \& Grzywaczewski, G. (2017). Diet of Rooks Corvus frugilegus and potential seed dispersal in urban and agricultural habitats of Romania and Poland. North-Western Journal of Zoology, 13(1), 94-100.
Kopylova, T. V., Koshelev, O. I., \& Koshelev, V. O. (2011). Dynamics of nesting raven population in control plots in 2000-2010 in the south of the Zaporozhye region (Northern Azov Sea region). Branta. Sbornyk nauchnykh trudov Azovo-Chernomorskoy ornytolohycheskoy stantsyy, 14, 94-105. [In Ukrainian].

Kövér, L., Tóth, N., Lengyel, S., \& Juhász, L. (2018). Corvid control in urban environments: a comparison of trap types. North-Western Journal of Zoology, 14(1), 85-90. Article No.: e171602.

Loparov, S. (2007). Population density of ravens (Corvidae L.) in the territory of Podillya in 1970-2006. (Ser. Biology). Bulletin of the Taras Shevchenko National University of Kyiv, 76-77. [In Ukrainian].

Madden, C. F., Arroyo, B., \& Amar, A. (2015). A review of the impacts of corvids on bird productivity and abundance. Ibis, 157(1), 1-16. https://doi.org/10.1111/ibi.12223

Marzluff, J. M., \& Neatherlin, E. (2006). Corvid response to human settlements and campgrounds: causes, consequences, and challenges for conservation. Biological conservation, 130(2), 301-314.

Marzluff, J. M., \& Restani, M. (1999). The effects of forest fragmentation on avian nest predation. Forest wildlife and fragmentation: management and implications. Brill, Leiden, The Netherlands, 155169.

Marzluff, J. M., Gehlbach, F. R., \& Manuwal, D. A. (1998). Urban environments: influences on avifauna and challenges for the avian conservationist. Avian conservation: research and management. Island Press, Washington, DC, 283-299.

Matyura, A. V., \& Zimaroeva, A. A. (2016). The synanthropization of corvids and the features of their adaptation to anthropogenic landscapes. Acta Biologica Sibirica, 2(1), 159-199. [In Russian].

Moroz, V. A., Galuyenko, S. V., \& Rusin, M. Yu. (2008). Data on the diurnal birds of prey population in the Provali steppe. Novitni doslidzhennya sokolopodibnykh ta sov: Proceedings of the III International scientific conference "The birds of prey in Ukraine". (pp. 274-278). Krivoy Rog. [In Russian].

Ravkin, Ye. S., \& Chelintsev, N. G. (1990). Methodical recommendations on integrated registration of birds along the route. Moscow: Izd. VNII Priroda, 33 p. [In Russian].

Roos, S., Smart, J., Gibbons, D. W., \& Wilson, J. D. (2018). A review of predation as a limiting factor for bird populations in mesopredator - rich landscapes: a case study of the UK. Biological Reviews, 93(4), 1915-1937. https://doi.org/10.1111/brv.12426

Sage, R. B., \& Aebischer, N. J. (2017). Does best-practice crow Corvus corone and magpie Pica pica control on UK farmland improve nest success in hedgerow-nesting songbirds? A field experiment. Wildlife Biology. https://doi.org/10.2981/wlb.00375

Špur, N., Pokorny, B., \& Šorgo, A. (2016). Attitudes toward and acceptability of management strategies for a population of hooded crows (Corvus cornix) in Slovenia. Anthrozoös, 29(4), 669-682. https://doi.org/10.1080/08927936.2016.1228766

Teplov, V. P., \& Turov, I. S. (2013). On the role of the Hooded Crow Corvus cornix in the floodplain hunting grounds of the middle course of the Oka River]. Russian Ornithological Journal, 22(888), 1570-1576. [In Russian].

Vetrov, V. V., \& Milobog, V. Ju. (1993). Composition and distribution of birds of prey in the Seversky Donets basin. Birds of the Seversky Donets Basin: Materialy konferentsii "Izucheniye i okhrana ptits basseyna Severskogo Dontsa". (pp. 33-38). Donetsk: DonGU. [In Russian].

Volchanetsky, I. B., Lisetsky, A. S., \& Kapralova, N. I. (1954). To the ornithofauna of the forests of the Seversky Donets Basin. Trudy NII biolog. f-ta Khark. gos. un-ta im. A. M. Gorkogo, 20, 33-45. [In Russian].

Yanish, Ye. Yu., \& Loparov, S. O. (2007). Wintering of corvids (Corvidae) on the territory of Kiev in modern conditions. Vestnik zoologii, 41(2), 143-152. [In Ukrainian].

Zawadzka, D., \& Zawadzki, G. (2014). Synanthropisation and synurbisation of Raven Corvus Corax in Poland. International Studies on Sparrows, 38(1), 11-16. https://doi.org/10.1515/isspar-2015-0025 
${ }^{1}$ Kharkiv National Agrarian University named after Dokuchaev, Kharkiv, Ukraine

${ }^{2}$ O. M. Beketov National University of Urban Economy, Kharkiv, Ukraine

${ }^{3}$ Luhansk Taras Shevchenko National University, Starobilsk, Ukraine

\section{POPULATION DYNAMICS OF CORVIDS AND THEIR INFLUENCE ON THE HUNTING FAUNA IN THE} LUHANSK REGION

Corvids (Corvidae) are spread in all continents except Antarctica and use of commonly available foods, both plant and animal. They are often considered as pests due to their noise, littering, aggression to humans and pets, and predation on birds in urban environment and hunting fauna in the field and forest. Climate change and anthropogenic factors have various effects on different corvid species, which compete for habitat and food. The aim of this study was to identify the features and causes of long-term dynamics of crow crowds, crows gray, magpies, roaches, pots, jugs in hunting grounds and to develop the recommendations for the regulation of their populations. Population dynamics of corvids was studied in 1983-2013 in hunting grounds of Shchetovske forestry in Ivanivske State Forest Hunting Enterprise of the Luhansk region. Population density of corvids was evaluated by route tracking without span and recalculated per $1 \mathrm{~km}^{2}$ by average distance of birds' detection. A raven (Corvus corax), hooded crow (Corvus (corone) cornix), rook (Corvus frugilegus), jackdaw (Corvus monedula), jay (Garrulus glandarius), and magpie (Pica pica) were registered the most often. For 30 years, population density of raven increased 11.5 times - from 0.1 to 1.15 specimens $/ \mathrm{km}^{2}$, and population density of hooded crow decreased 11.1 times - from 3.4 to 0.3 specimens $/ \mathrm{km}^{2}$, population density of magpie, rook, jackdaw, and jay decreased 2.4, 9.2, 2, and 1.6 times respectively. Population density of raven has a negative correlation with population density of other corvids, and correlation index was the highest with population density of hooded crow. These two corvids have close ecological features, but a raven is larger and more aggressive bird. Dependence of population density of different corvids from feeding habits, places of settlement, harmfulness for hunting objects and anthropogenic factors has been analyzed. Simplified permission for raven hunting was recommended to decrease its damage to hunting fauna (mallard and other ducks, pheasant, gray partridge and brown hare).

Keywords: Raven; Hooded Crow; Magpie; Rook; Jackdaw; Jay. 